\title{
Studies on the Maintenance of the Adrenalectomized Patients with Advanced Cancer of the Breast Masaaki OKUMURA M.D.
}

Second Department of Surgery, Nagoya University, School of Medicine

(Chief : Prof. Hajime Imanaga)

During the past seven years or so, adrenalectomy has been consisdered advisable for 43 patients with advanced cancer of the breast and for whom the possibilities of direct surgery or irradiation and hormone therapy have been exhausted.

With the advent of hydrocortisone, total adrenalectomy became a practical considera tion, and it has been supplied as the only drug for replacement therapy after the ablative procedures. However, in recent years, various glucocorticoids such as hydrocortisone, cortisone, prednisolone, 6-methyl-prednisolone, triamcinolone and dexamethasone have become available. Therefore, if we could select more adequate activities of glucocorticoids for replacement therapy than that of cortisone, it would be desirable for the adrenalectomized patients to give them a sense of well being without unwanted side effects for a long term after adrenalectomy.

From this point of view, all the adrenalectomized patients, on whom we employed various glucocortidcoids as replacement therapy, were observed through 1) clinical signs and symptoms, 2) various side effects, 3) maintenance of daily blood pressure normal, 4) urinary exretion of sodium and potassium, 5) liver function, 6) carbohydrate metabolism.

Conclusions are as follows:

1) From the clinical observation, single glucocorticoid such as prednisolone, 6-methylprednisolone, triamcinolone, dexamethasone at equivalent doses of glucocorticoid activity of hydrocortisone (20 mg of hydrocortisone in daily dosis) was not capable of maintaining the adrenalectomized patients and could not prevent the development of symptoms of adrenal insufficiency (weakness, fatigue, nausea, vomiting and hypotension).

2) In the adrenalectomized patients maintained on hydrocortisone or cortisone, their urinary excretion of sodium and potassium was within the nornal limits and the serum sodium and potassium concentration was also within the normal limits. On the other hand, urinary excretion of sodium and potassium in the patients maintained on prednisolone, 6-methyl-prednisolone, triamcinolone and dexamethasone, was increased.

3) Evaluation of blood sugar, pyruvic acid, lactic acid following the ingestion of glucose in the adrenalectomized patients.

a) In the adrenalectomized patients maintained on hydrocortisone, cortisone, or prednisolone, the blood sugar curve was almost mormal. Blood pyruvic acid level reached the maximum in 30 to 60 minutes after the ingestion of glucose, and fell to 
the fasting level within 3 hours. Blood lactic acid level showed a parallel curve to that of pyruvic acid.

b) Blood sugar, pyruvic acid, lactic acid curve of the patients maintained on 6methyl-prednisolone, triamcinolone, or dexamethasone showed sligtly diabetic in some cases. There was a significant rise in the level of pyruvic acid, and it remained elevated even 3 hours after the ingestion of glucose.

4) Serum level of albumin was reduced and the level of serum globulin remained elevated in many of the adrenalectomized patients manintained on cortisone.

5) Replacement therapy was withdrawn from adrenalectomized patients under carefully controlled conditions. On the third to fourth day of withdrawal, all the patients developed the symptoms of adrenal insufficiency. No adrenalectomized patients were capable of maintaining their lives without the administration of the parenteral glucocorticoid.

6) Hydrocortisone $20 \mathrm{mg}$ daily provides the most adequate replacement therapy for the adrenal glucocorticoids, in the long term treatmet of the adrenalectomized patients. The administration of DOC and supplementary salt was not necessary.

(pp. 1566 1580) 


\title{
副腎全剔患者の維持に関する研究
}

\author{
名古屋大学医学部今永外科（主任：今永一教授） \\ 奥 村 昌 明
}

（昭和39年12月12日）

目

$\begin{aligned} & \text { 第 } 1 \text { 章 緒 } \quad \text { 言 } \\ & \text { 第 } 2 \text { 章 研究方法 } \\ & \text { 第 } 1 \text { 節 } \text { 研究対象 } \\ & \text { 第 } 2 \text { 節 } \text { 用いた Adrenal Steroid の種類 } \\ & \text { 投与法 } \\ & \text { 第 } 3 \text { 節 } \text { 臨床症状 } \\ & \text { 第 } 4 \text { 節 } \text { 尿中電解質排泄量の測定 } \\ & \text { 第 } 5 \text { 節 } \text { 肝 機 能 } \\ & \text { 第 } 6 \text { 節 } \text { ブドウ糖負荷試験 } \\ & \text { 1) ブドウ糖経口投与法 } \\ & \text { 2) 採血方法 } \\ & \text { 3) 血糖値測定法 } \\ & \text { 4) 焦性ブドウ酸定量法 } \\ & \text { 5) 乳酸定量法 }\end{aligned}$

第3 章 成 績

第 1 節 臨床症状及び血庄の推移について

1) Prednisolone $5 \mathrm{mg} /$ day による維 持

2) Prednisolone 10mg/dayによる維 持

3) 6-Methyl-prednisolone 12mg/ day 持維による

4) Triamcinolone $4 \mathrm{mg} /$ day による 維持
次

5) Dexamethasone $1 \mathrm{mg} /$ day による 維持

6) Cortisone $25 \mathrm{mg} /$ day による維持

7) Hydrocortisone $20 \mathrm{mg} /$ day によ る維持

第 2 節 尿中及び血中電解質の推移

1) 維持別の尿中電解質排泄量

2）血中電解質の推移

第 3 節 肝 機 能

第 4 節 糖負荷試験による血桾，焦性ブド ウ酸, 乳酸值の消長について

1）維持別にみた血糖, 焦性ブドウ酸, 乳酸值

1）血糖 值

ロ）焦性ブドウ酸值

八）乳酸值

2) ブドウ糖経口負荷試験による血糖 焦性ブドゥ酸, 乳酸值の消長につ いて

第 5 節 副腎全剔患渚の維持中止試験

第 6 節 副腎全剔患渚に対する外科的浸襲 第 4 章 考 按 第 5 章 結 諭

\section{I 緒}

言

1952年 Huggins ${ }^{1)}$ は遠隔転移や広範な局所再発を持つ所謂末期乳癌に対して，両側副腎全剔術を行ない効 果を収めた，之は乳癌の発生に重要な因子と考元れれている Estrogen 分泌源を除くとの考えによるもので ある。以来諸外国では Hellström ${ }^{2)}$ ， Rearson ${ }^{3) ， W h i t e m o r e ~}{ }^{4)}$ ， Galante ${ }^{5)}$ らの多数の報告があり，教室でも 1956年以来副腎外科症例は68例に及び，その中，両側副腎全剔術を行なつた患者は43例を数えている．対象 が末期乳癌であることからあくまで姑息的手術であるてとはいなめないが，副腎全剔術は教室の症例では約 50\%に有効であり従つて副腎全剔術は未期乳癌患者に対して試みらるべき手術であるということができる. 


\begin{tabular}{|c|c|c|c|c|c|c|c|c|c|c|c|c|c|}
\hline 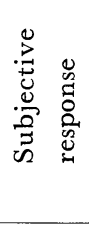 & + & + & 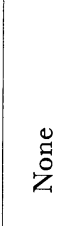 & 艺 & $\stackrel{0}{0}$ & & + & + & 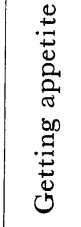 & 苂 & 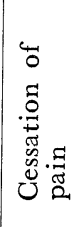 & 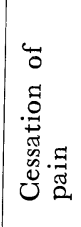 & : \\
\hline 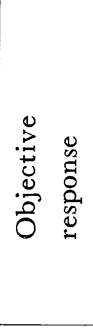 & 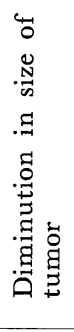 & 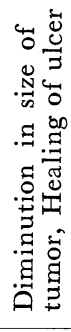 & $\begin{array}{l}\ddot{0} \\
\stackrel{0}{z}\end{array}$ & : & $\begin{array}{l}0 \\
\ddot{Z} \\
z\end{array}$ & & 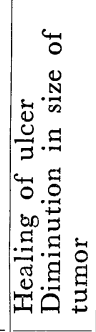 & 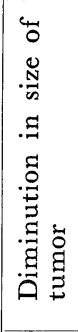 & 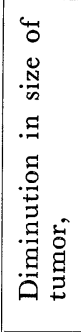 & $\begin{array}{l}0 \\
\ddot{Z}\end{array}$ & $\begin{array}{l}\text { : } \\
\text { Z }\end{array}$ & 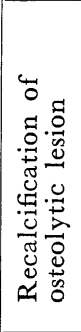 & 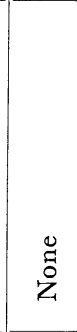 \\
\hline 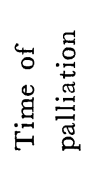 & 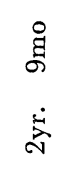 & $\begin{array}{l}\text { ̊̆ } \\
\dot{\check{\alpha}}\end{array}$ & 1 & 1 & 1 & & $\begin{array}{l}\dot{8} \\
\dot{\Delta} \\
\dot{\Delta}\end{array}$ & $\stackrel{\dot{g}}{\stackrel{\dot{g}}{\Xi}}$ & ğ & 1 & 1 & $\begin{array}{l}\dot{g} \\
\dot{\Xi} \\
\dot{\Xi}\end{array}$ & 1 \\
\hline 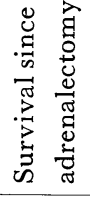 & 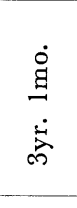 & $\begin{array}{l}\dot{\circ} \\
\dot{g} \\
\dot{5}\end{array}$ & $\stackrel{\vec{U}}{\vec{A}}$ & 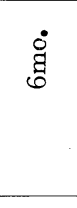 & $\stackrel{\stackrel{\Xi}{\theta}}{\ddot{\theta}}$ & 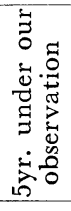 & 亲 & $\begin{array}{l}\dot{0} \\
\dot{\Xi} \\
\dot{\Sigma}\end{array}$ & $\begin{array}{l}\dot{0} \\
\stackrel{\Xi}{\Xi} \\
\dot{\hat{d}}\end{array}$ & 客 & $\dot{g}$ & $\begin{array}{l}\dot{\text { g }} \\
\text { ले } \\
\text { ¿े }\end{array}$ & 昌 \\
\hline 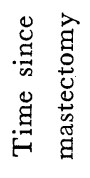 & 0 & 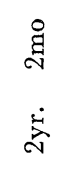 & 芯 & $\dot{\dot{g}}$ & : & $\dot{g}$ & 1 & 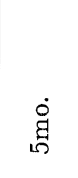 & 离 & 灾 & $\begin{array}{l}\dot{\dot{g}} \\
\text { जे } \\
\dot{\Delta}\end{array}$ & के & 1 \\
\hline 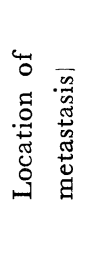 & 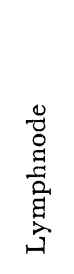 & 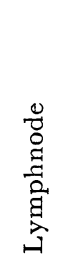 & 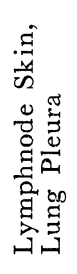 & 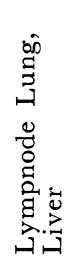 &  & 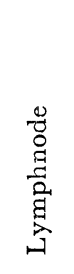 & 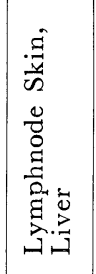 & 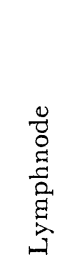 &  & 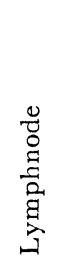 & 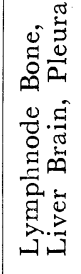 & 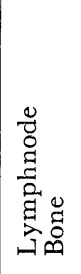 & 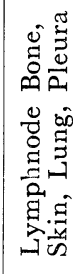 \\
\hline 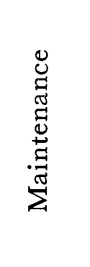 & 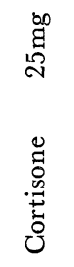 & 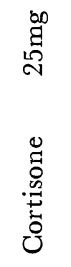 & 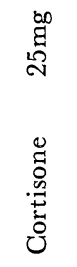 & 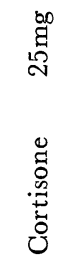 & 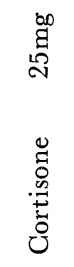 & 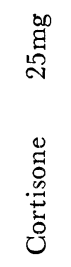 &  & 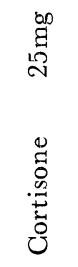 & 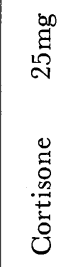 & 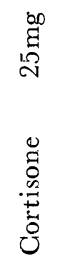 & 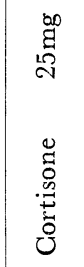 & 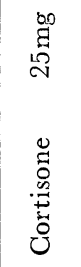 & 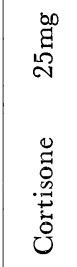 \\
\hline 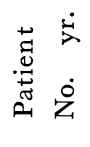 & $\begin{array}{l}H \\
m\end{array}$ & $\begin{array}{l}\text { H } \\
\dot{H}\end{array}$ & $\begin{array}{l}\stackrel{7}{7} \\
\end{array}$ & $\begin{array}{l}\text { m } \\
=\end{array}$ & $\begin{array}{l}\stackrel{\sim}{ } \\
\text { N }\end{array}$ & $\ddot{\circ}$ & $\begin{array}{l}g \\
\stackrel{9}{9}\end{array}$ & $\begin{array}{l}\infty \\
\infty \\
\infty\end{array}$ & เి & 品 & in & $\begin{array}{l}\text { 우 } \\
\text { 이 }\end{array}$ & श \\
\hline
\end{tabular}




\begin{tabular}{|c|c|c|c|c|c|c|c|c|c|c|c|c|c|c|}
\hline 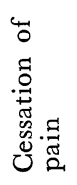 & 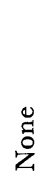 & + & 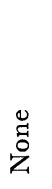 & & 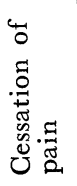 & & + & + & & $\begin{array}{l}\text { Ŭ } \\
\text { Z }\end{array}$ & 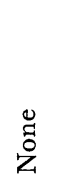 & 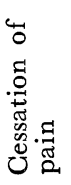 & & + \\
\hline 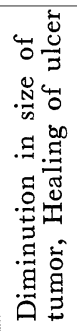 & 苂 & 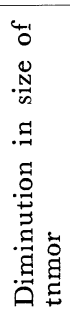 & $\begin{array}{l}0 \\
\text { Z } \\
\text { z }\end{array}$ & \multirow{3}{*}{ 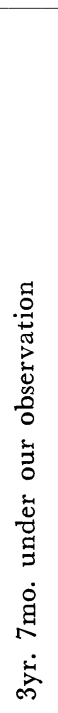 } & 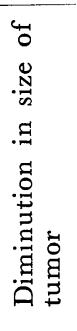 & 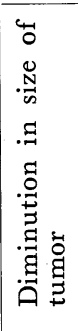 &  & 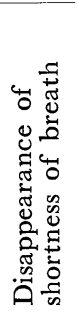 & & $\begin{array}{l}\text { ̊̈ } \\
\text { Zे }\end{array}$ & 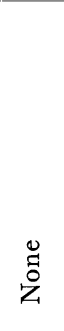 & + & \multirow{3}{*}{  } & 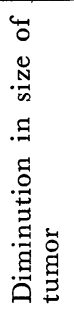 \\
\hline & 1 & $\begin{array}{l}\dot{\delta} \\
\text { ڤ̆ } \\
\dot{\Sigma}\end{array}$ & 1 & & $\begin{array}{l}\dot{\circ} \\
\text { ğ } \\
\dot{\vec{\lambda}}\end{array}$ & & $\begin{array}{l}\dot{\circ} \\
\dot{g} \\
\dot{\Sigma}\end{array}$ & $\dot{g}$ & $\dot{\Xi}$ & 1 & 1 & $\dot{\text { ğ }}$ & & 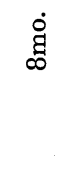 \\
\hline$\dot{g}$ & $\begin{array}{l}\widetilde{d} \\
. \vec{\theta}\end{array}$ & $\begin{array}{l}\dot{\circ} \\
\text { ఫ̆ } \\
\dot{\grave{~}}\end{array}$ & $\dot{g}$ & & $\begin{array}{l}\dot{\Xi} \\
\text { ğ } \\
\dot{\vec{\lambda}}\end{array}$ & 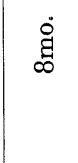 & $\begin{array}{l}\dot{\leftrightarrow} \\
\infty \\
\dot{\Xi} \\
\dot{\Xi}\end{array}$ & $\begin{array}{l}\dot{0} \\
\text { ठํ } \\
\dot{\Xi}\end{array}$ & $\begin{array}{l}\dot{\circ} \\
\dot{\Xi} \\
\dot{\Xi}\end{array}$ & 䙷 & $\dot{g}$ & छ్̊̆ & & $\begin{array}{l}\dot{\Xi} \\
\text { ㄱ } \\
\dot{\Xi}\end{array}$ \\
\hline 1 & 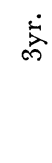 & 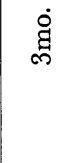 & 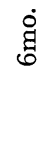 & $\dot{\theta}$ & 염 & 1 & 1 & 1 & 1 & $\dot{\Sigma}$ & $\begin{array}{l}\dot{\leftrightarrow} \\
\text { ন } \\
\dot{\vec{\lambda}}\end{array}$ & $\begin{array}{l}\dot{\circ} \\
\text { 品 } \\
\dot{\text { N }}\end{array}$ & ๕̊̆ & $\begin{array}{c}\dot{\leftrightarrow} \\
\text { g̊ } \\
\dot{\vec{\Delta}}\end{array}$ \\
\hline 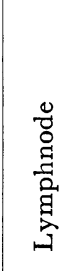 & 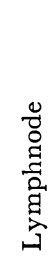 & 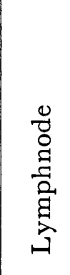 & 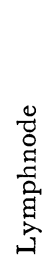 &  & 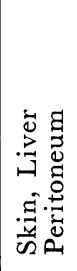 & 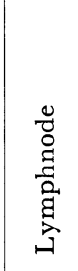 & 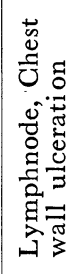 & 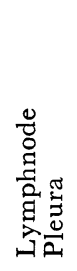 & & 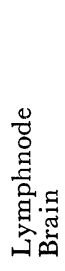 & 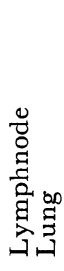 & 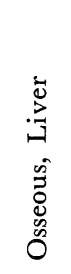 & 气 & 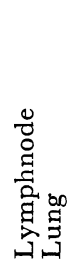 \\
\hline 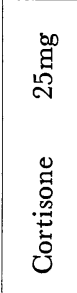 & 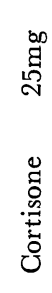 & 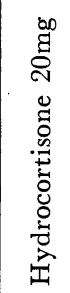 & 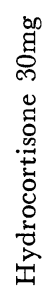 & 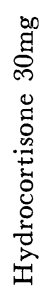 &  & 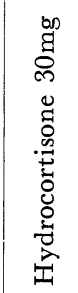 & 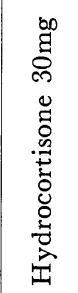 & 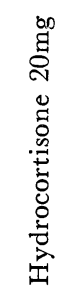 & 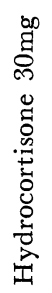 & 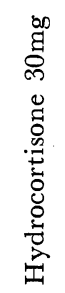 & 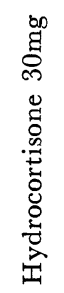 & 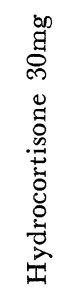 & 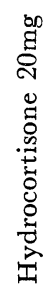 & 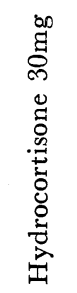 \\
\hline $\overrightarrow{6}$ & $\mathcal{F}$ & o & P & in & $\mathcal{F}$ & $\infty$ & 8 & i̊ & $\infty$ & 아 & "े & i & $\hat{\infty}$ & $\mathscr{q}$ \\
\hline $\mathscr{m}$ & $\hat{m}$ & $\infty$ & 우 & $F$ & F & $\mathbb{F}$ & 2 & $\mathscr{q}$ & f & $\stackrel{\infty}{\&}$ & F & in & $\vec{n}$ & ชิ \\
\hline
\end{tabular}




\begin{tabular}{|c|c|c|c|c|c|c|c|c|c|c|c|c|c|c|}
\hline 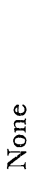 & 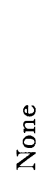 & & 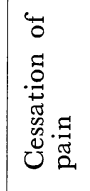 & 苋 & 芩 & $\begin{array}{l}0 \\
0 \\
z \\
z\end{array}$ & 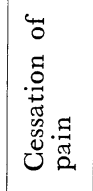 & $\begin{array}{l}0 \\
\text { ̊̆ } \\
z\end{array}$ & 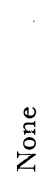 & & 号 & $\begin{array}{l}0 \\
z\end{array}$ & 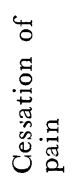 & \\
\hline 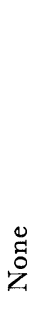 & $\begin{array}{l}\text { : } \\
\text { ż }\end{array}$ & 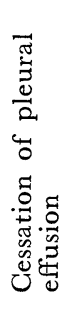 & 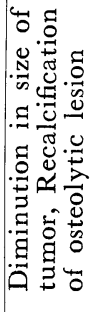 & 号 & $\begin{array}{l}0 \\
\text { : }\end{array}$ & 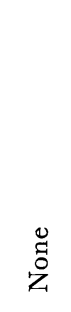 & 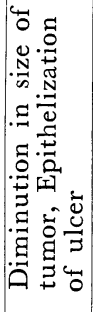 & $\begin{array}{l}\stackrel{0}{0} \\
\check{0}\end{array}$ & $\begin{array}{l}\ddot{0} \\
\check{z}\end{array}$ & 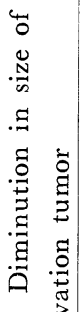 & 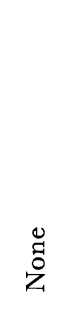 & 芩 & 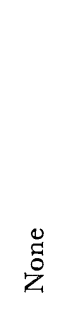 & \\
\hline 1 & 1 & g் & 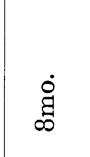 & I & 1 & 1 & 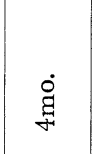 & I & 1 & 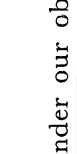 & 1 & 1 & & 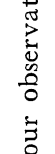 \\
\hline 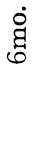 & ๕্் & $\begin{array}{l}\dot{g} \\
\dot{\Xi} \\
\dot{\Xi}\end{array}$ & 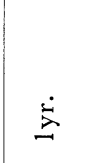 & 苛 & $\dot{\mathrm{g}}$ & $\dot{\grave{g}}$ & 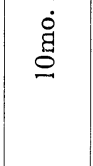 & 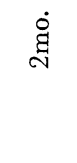 & 完 & $\begin{array}{l}\dot{\dot{g}} \\
\dot{\Delta} \\
\dot{\Xi}\end{array}$ & ๕̆ & ஷ் & 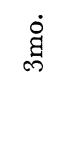 & 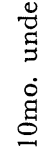 \\
\hline 1 & \&̊̆ & 紊 & స્ટ & $\stackrel{\Sigma}{\Sigma}$ & 离 & $\dot{\vec{z}}$ & 1 & $\begin{array}{l}\dot{\circ} \\
\text { ğ } \\
\dot{\vec{\lambda}}\end{array}$ & $\begin{array}{l}\dot{g} \\
\dot{g} \\
\dot{\Sigma}\end{array}$ & $\Xi$ & & $\begin{array}{l}\dot{\mathscr{D}} \\
\dot{0} \\
\dot{g}\end{array}$ & & 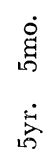 \\
\hline 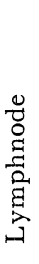 & 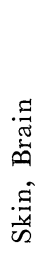 & $\frac{\overparen{g}}{3}$ & 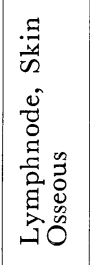 & 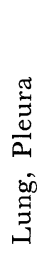 & 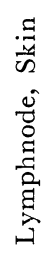 &  & 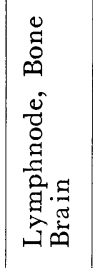 & 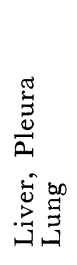 & 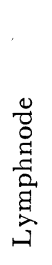 & 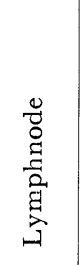 & 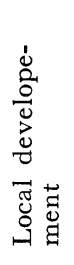 & 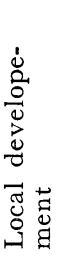 & 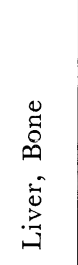 & 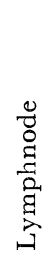 \\
\hline 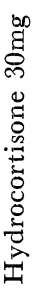 & 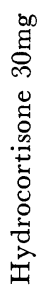 & 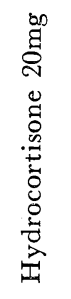 & 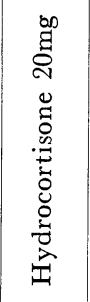 &  & 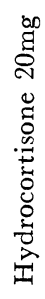 & 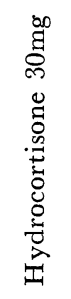 & 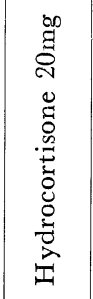 & 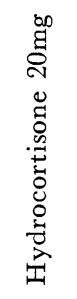 & 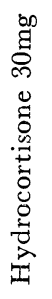 & 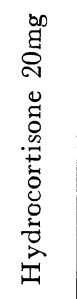 & 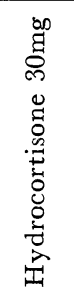 & 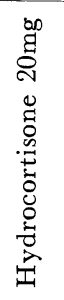 & 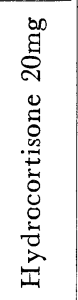 & 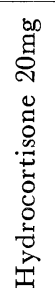 \\
\hline กี & $\stackrel{\infty}{\infty}$ & in & 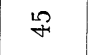 & $\widetilde{6}$ & 尔 & $\stackrel{\mathscr{q}}{*}$ & in & 号 & $\ddot{g}$ & लै & 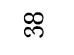 & in & in & $\overrightarrow{0}$ \\
\hline in & 点 & กี & in & in & $\stackrel{\infty}{\circ}$ & in & 8 & ชิ & $\tilde{6}$ & ठే & 80 & 8 & 6 & $\infty$ \\
\hline
\end{tabular}


しかし，両側の副婜を全剔すると内分泌環境の急変があり，物質代謝障碍が㧍てるので Glucocorticoids による維持が不可欠である。近時各種合成 Steroid が実用に供されるようになつたが，副腎全剔患者の維 持 Steroid としては次の様な性質を持つととが望ましい，即ち 1) 一般状態が長期間にわたつて正常に維 持されること，換言すれば，糖，蛋白，電解質代謝，肝機能，血圧等が正常に維持されなければならない，

2) 浮腫，肥満等の副作用がないてと．3）投与法が容易であるとと４）投与 Corticoids から Estrogenic Substance への転換の可能性を考えると出来るだけ少量で維持でき且つ構造上転換しがたい Steroidが望ま しい.

Huggins 以来副婜全剔後の置換療法 (replacement therapy) として Cortisone が一般的に用いられて いるが，市販になつている各種合成 Steroids の中に Cortisone よりも上述の点で優れた薬剤があれば，一 層望ましいことである。かかる観点からこれらの合成 Steroids を用い，臨床症状，副作用の有無，血圧の 保持尿中電解質の排泄，肝機能，糖代謝について観察した.

\section{II 研 究 方 法}

\section{1. 研究対象}

1956年より1963年に至る 7 年闒に今永外科教室に於いて副掔外科を行なつた末期乳癌患者は68例で，その 中副腎全剔患者は43例である。(Table 1)

\section{2.用いた Adrenal Steroid の種類，投与法}

使用せる Adrenal Steroids は Hydrocortisone, Cortisone, Prednisolone, 6-Methyl-Prednisolone, Triamcinolone, Dexamethasone の 6 種類で経口的に朝 1 回又は半量づつ朝夕 2 回に分けて投与している. それぞれの Hormone のNa-貯溜作用，糖質作用等は，Soffer ${ }^{6)}$ そよれ゙，Table 2 の如くである，Bondy

Table 2. Comparative Effects of the Adrenal Steroids on Sodium Retention

Potassium Diuresis, Protein and Carbohydrate Metabolism, and on the Inhibition of the Adenopophyseal Elaboration of Corticotropin

\begin{tabular}{|c|c|c|c|c|}
\hline Hormonal Agent & $\begin{array}{l}\text { Sodium } \\
\text { Retaining } \\
\text { Effects }\end{array}$ & $\begin{array}{l}\text { Potassium } \\
\text { Diuretic } \\
\text { Effects }\end{array}$ & $\begin{array}{l}\text { Effect on } \\
\text { Protein and } \\
\text { Carbohydrate } \\
\text { Metabolism }\end{array}$ & $\begin{array}{l}\text { Inhibition of the } \\
\text { Adenohypophyseal } \\
\text { Secretion of } \\
\text { Corticotropin }\end{array}$ \\
\hline Cortisone & 1 & 1 & 1 & 1 \\
\hline Cortisol & 1.25 & 1 & 1.25 & 1.25 \\
\hline Prednisolone & none & slight & $3 \sim 5$ & $3 \sim 5$ \\
\hline $\begin{array}{l}\text { 6-Methyl- } \\
\text { Prednisolone }\end{array}$ & none & slight & $4 \sim 6$ & $3 \sim 5$ \\
\hline Triamcinolone & none & $?$ & $4 \sim 6$ & $3 \sim 5$ \\
\hline Dexamethasone & none & $?$ & $25 \sim 35$ & $25 \sim 35$ \\
\hline
\end{tabular}

らによると経静脈カテーテル法を用いて 副腎から分泌される 17-Hydroxy-Corticosteroids を測定して， 人の副腎からは 1 日に凡そ $25 \mathrm{mg} の$ Hydrocortisone が分泌されると述べている. 教室では Hydrocortisone $20 \mathrm{mg}$ の糖質作用に相当する量をその基準として用いた。更に Na-貯溜作用を補う目的で DOCも使 用した。

\section{3. 臨床症状}

上記合成 Steroids を用いて副袩全剔後の維持を行ない，血圧を測定，浮腫，肥満，高血圧，満月様顔貌， 多毛，男性化等の副作用の有無について臨床的に観察した. 
4. 尿中電解質排泄量の測定には，日立の分光光度計の附属装置である焰光々度計を用いた，吸収スペク トルは Na $589 \mathrm{~m} \mu ., \mathrm{K} 768 \mathrm{~m} \mu$ の波長について測定した.

\section{5. 肝機 能}

Hydrocortisone 20mg〜30mg 維持群及び Cortisone 25mg 維持群について, 血清総蛋白, Albumin, Globulin, T.T.T. C.G.F. Cholesterol, B.S.P. alkali-phosphatase, G.O.T. G.P.T. 等について 術後長期間 にわたり検索を行なつた.

\section{6.ブドウ糖負荷試験}

1) ブドウ糖 $30 \mathrm{~g} 2$ 回経口投与法, $50 \mathrm{~g}$ 経口投与法により, 血煻值, 焦性ブドウ酸値, 乳酸值を測定し てブドウ糖負荷後 3 時間にわたりその消長について観察した。

2) 採血方法

運動, 食事, うつ血等による影響をさけるために早朝空腹時に肘静脈より採血した。焦性ブドウ酸值に影 響を与える薬剈, 糖, ビタミン等は検查の数日前からさけた，尚 Steroid Hormone は検査終了後に投与 した.

\section{3) 血糖値測定法}

Hagedorn-Jensen 法を用いた。

4) 焦性ブドウ酸定量法

焦性ブドウ酸定量法で最も簡単なのは Clift \& Cookら ${ }^{8)}$ の重雨硫酸法であるが，その後 Friedman., Ho-

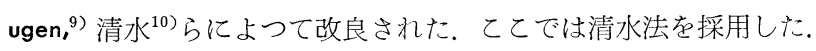

5) 乳酸定量法

Barker-Summerson 法 ${ }^{11)}$ につた。

$$
\text { III 成 績 }
$$

\section{1. 臨床症状及び血圧の推移について}

1) Prednisolone $5 \mathrm{mg} /$ day による維持

症例25.49才女子, 左乳癌の進行せる患者で，1959年 8 月12日に雨側副腎全剔術を行なつた。術後 2 ケ月 経過してから Cortisone $25 \mathrm{mg}$ による維持を Prednisolone $5 \mathrm{mg}$ に変えて維持すると（Fig. 1) 約 1 ケ月

Fig. 1. Clinical course of a 49year-old woman after adrenalectomy, in response to the maintenance of Prednisolone 5mg a day

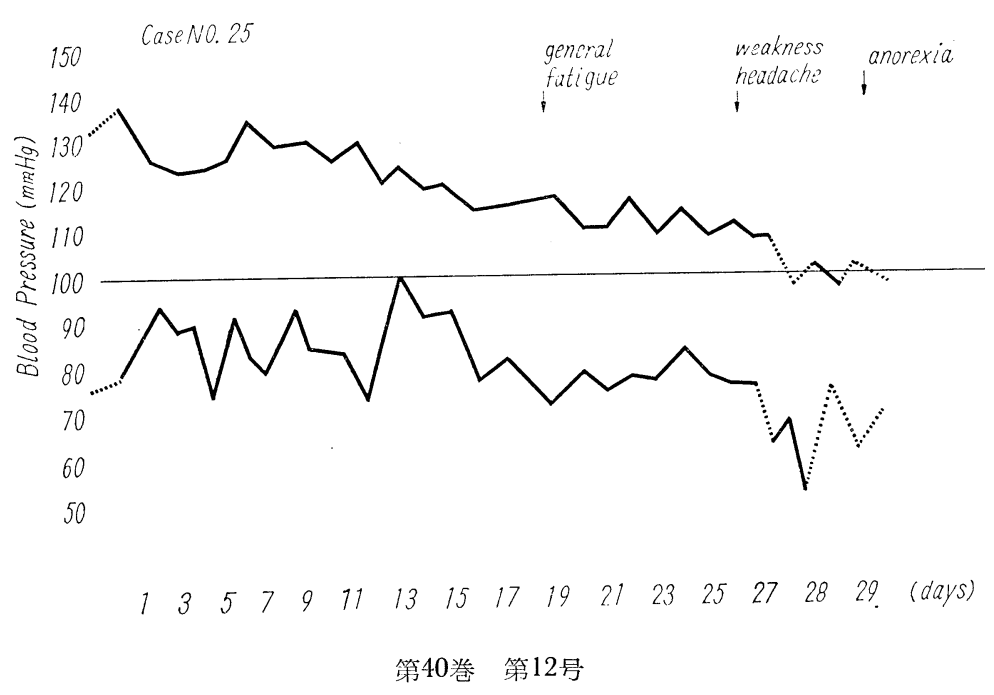


後には全身倦急感著明となり，頭痛，耳鳴，食思不振，血圧下降等副腎不全の徵候発現し，Cortisone の投 与で速かに症状が改善された，従つて Prednisolone 5mg による維持は不可能である.

2) Prednisolone $10 \mathrm{mg} /$ day による維持

4 名の副腎全剔患者に就て行なつたが，副作用なくほぼ維持が可能であつた，しかし，Glucocorticoid としては Hydrocortisone 40mg に相当し大量にすぎて，漸次満月様顔貌，肥満の傾向が出現し中止のやむ なきに至つた。

\section{3) 6-Methyl-prednisolone $12 \mathrm{mg} /$ day による維持}

同じく症例25に対して維持を試みたが，12日目に耳鳴，頭痛が高度となり維持は不可能であつた，Glucocorticoid としては大量であり，長期間の維持はできない. 6-Methyl-prednisolone は Na-貯溜作用が非常 に弱いので，乙れを補う目的で，6-Methyl-prednisolone 8mg 経口投与に DOC. 5mg 週 2 回筋注を加えて

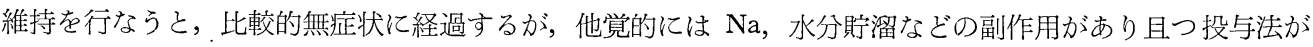
繁雑でしかも電解質代謝の調節がむづかしく，乙れも長期間の維持には不適当である.

\section{4) Triamcinolone $\mathbf{4 m g} /$ day による維持}

症例26.1959年，9月9 日に両側副腎全剔術を行なつている。術後 2 ケ月目に Triamcinolone $4 \mathrm{mg} / \mathrm{day}$ で維持を行なうと（Fig. 2) 全身倦急感が強く現われ，食思不振，嘔吐を伴い11日目には，血圧が下降，頭

Fig. 2. Clinical course of a 38 year-old woman after adrenalectomy, in response to the maintenance of Triamcinolone $4 \mathrm{mg}$ a day

Case No. 26

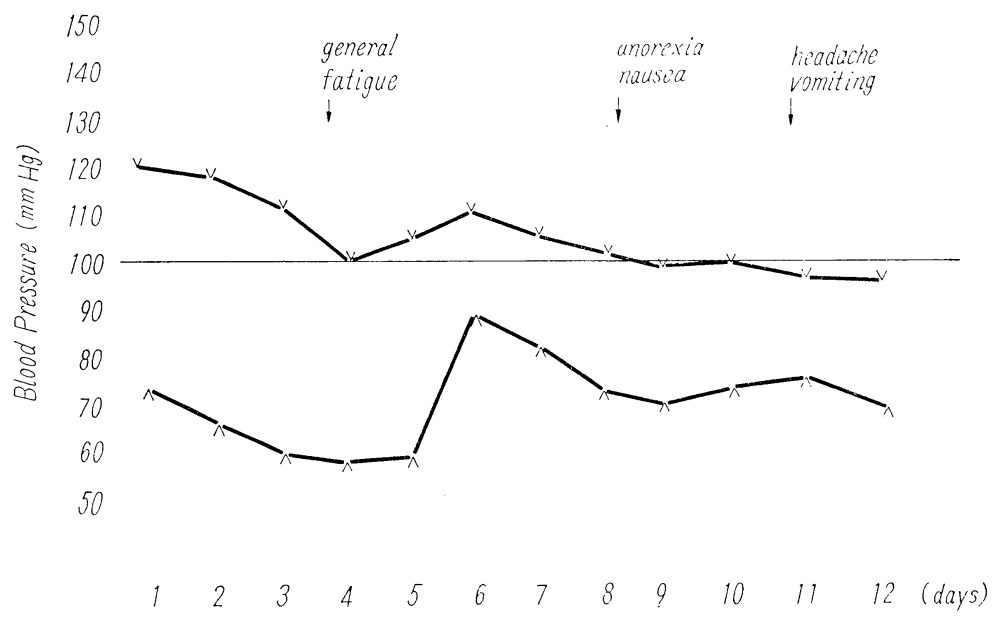

痛嘔吐等の副腎不全の症状が発現し維持が不可能となつた。

症例53にも同様に Triamcinolone $4 \mathrm{mg} / \mathrm{day}$ によ維持を試みたが副作用のため維持はできなかつた。

症例46に対しては，Triamcinolone $8 \mathrm{mg} / \mathrm{day}$ と増量して維持を試みたが，20日目に高血圧発作をおてし 維持は不能となつた. Hydrocortisone $20 \mathrm{mg}$, Cortisone $25 \mathrm{mg}$ 相当量では副腎不全症状が発現し, 倍量では 副作用として高血圧を招来した，從つて Triamcinolone は適量の決定が困難であり replacement therapy としては用い難い.

5) Dexamethasone $1 \mathrm{mg} /$ day による維持

症例 $26 ， 46 ， 52 の 3$ 名に Dexamethasone $1 \mathrm{mg} / \mathrm{day}$ にる維持を試みたが，いずれも 全身倦急感，嘔 吐，食思不振等が現われた。 Dexamethasone を $5 \mathrm{mg}$ に増量すると，一般状態に著変なく維持が可能だが， 
Glucocorticoid としては非常に大量であり，過コルチコイド症状を呈するととは不可避である.

\section{6) Cortisone $25 \mathrm{mg}$ による維持}

両側副腎全剔症例43例中12例に Cortisone 25３7.5mg による維持を行なつている. 臨床的には副作用は 認められず長期間の維持が可能である.

Table 3. Urinary excretion of sodium and potassium after adrenalectomy, in response to various change in adrenal replacement program

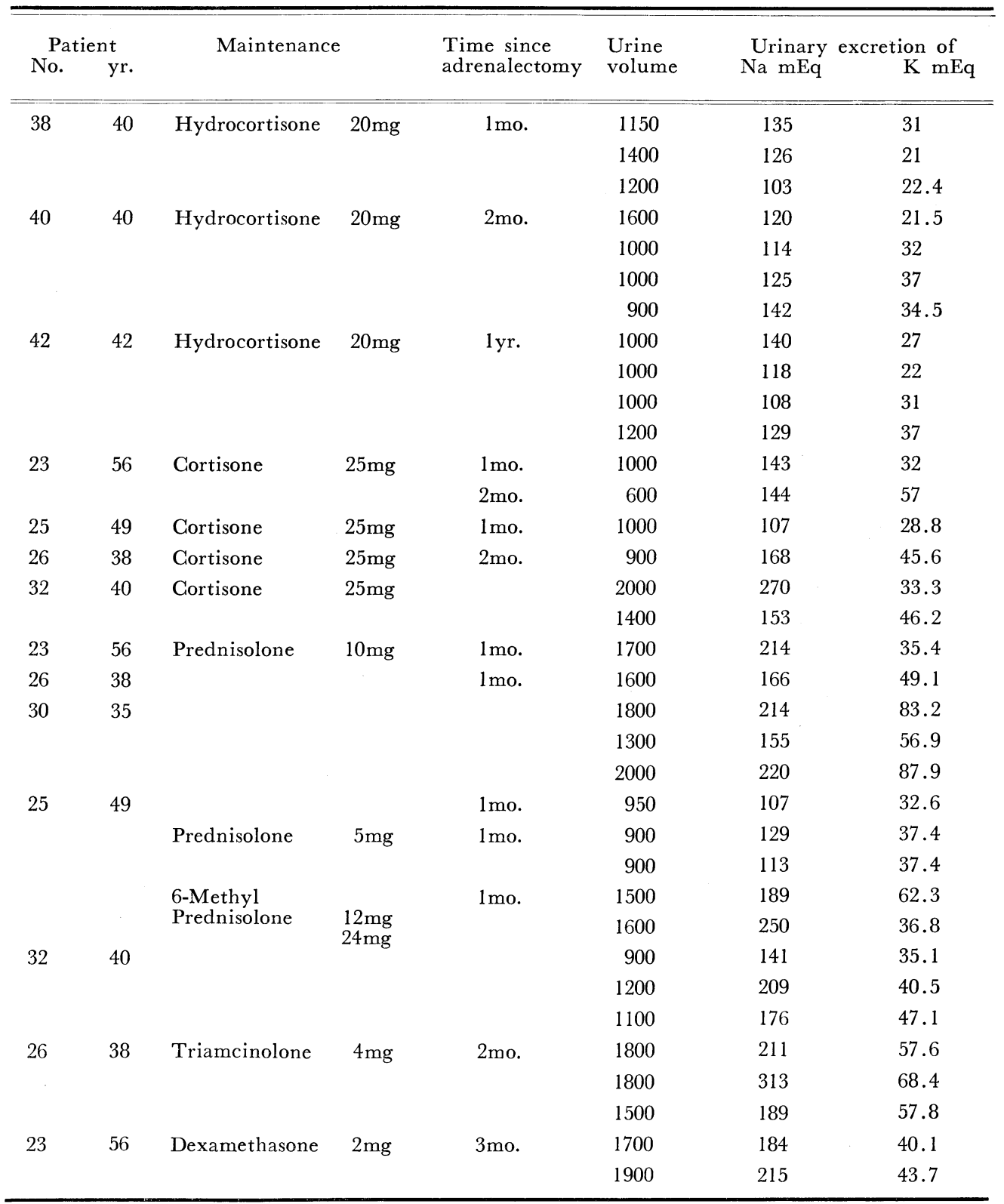


7) Hydrocortisone による維持

副腎全剔患者28例に Hydrocortisone 20〜30mg による維持を行なつた. 多くの症例は1日20 mg〜30mg の投与で允分で，40 mgを必要とした症例は少なく，且つ一時的な投与であり，㙊期間 $40 \mathrm{mg}$ を必要とした 症例はなかつた。

\section{2. 尿中及び血中電解質の推移}

\section{1) 維持別の尿中電解質の排泄量}

Table 3. に示すごとく, Prednisolone 10mg, 6-Methyl-prednisolone 12mg, $24 \mathrm{mg}$, Triamcinolone $4 \mathrm{mg}$, Dexamethasone $2 \mathrm{mg}$ による維持例には Na の尿中排泄量が増加している。 Na-貯溜作用が少ない これら glucocorticoid の生理作用より当然考えられることである.

\section{2) 血中電解質の推移}

Fig. 3 は副腎全剔後 Hydrocortisone で維持された患者で，術後 1 ケ月〜 3 年 2 ケ月にわたる経過をみ

Fig. 3. Serum electrolyte evaluation of adrenalectomized patients maintained on Hydrocortisone

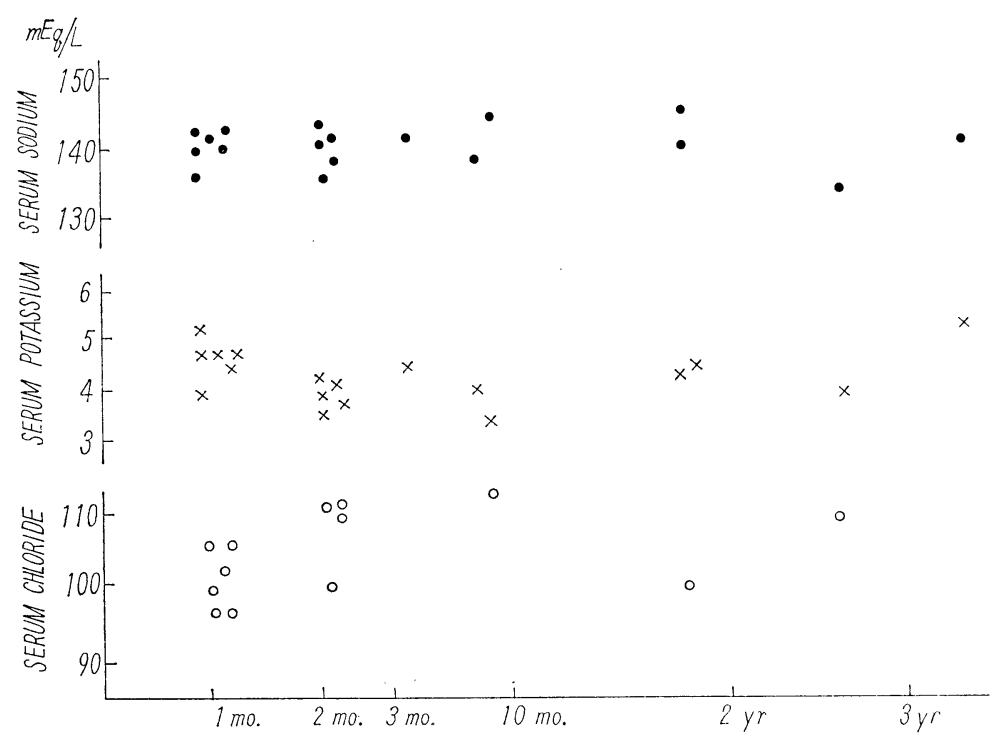

たものである．血清Naは $132 \mathrm{mEq} / \mathrm{L} \sim 146 \mathrm{mEq} / \mathrm{L}$ と正常範团にあり，血清 $\mathrm{K} は 3.3 \mathrm{mEq} / \mathrm{L} \sim 5.2 \mathrm{mEq} / \mathrm{L}$ で これ又正常範囲にある。

\section{3. 肝 機 能}

Hydrocortisone $20 \mathrm{mg} \sim 30 \mathrm{mg}$ /day 維持群14例及び, Cortisone $25 \mathrm{mg} /$ day 維持群 7 例の両群について術 後 1 ケ月以降の肝機能について観察すると Fig. 4 の如くである. 即ち Cortisone による維持群に於て血 清蛋白は $8.7 \mathrm{~g} / \mathrm{dl} \sim 5.8 \mathrm{~g} / \mathrm{dl}$ で血清 Albumin 值は $2.8 \mathrm{~g} / \mathrm{dl} \sim 4.3 \mathrm{~g} / \mathrm{dl}$ で軽度の低下を示し，血清 Globulin 值は $3.6 \mathrm{~g} / \mathrm{dl} \sim 4.8 \mathrm{~g} / \mathrm{dl}$ と上昇している. 高田反応, T.T.T. G.G.F に障害がみられ, B.S.P. の排泄 遅延がある. Hydrocortisone による維持群の血清蛋白は $6.3 \mathrm{~g} / \mathrm{dl} \sim 7.8 \mathrm{~g} / \mathrm{dl}$ と正常範囲にあり, 他の肝機 能検查にも異常はみられない. しかし Cortisone により維持を行なつた症例でも 2 年以上長期にわたり， 肝機能を経過観察してみると, Table 4 のでとく正常に維持されているものもある. 即ち Cortisone によ る維持の全例に肝機能障害がくるとは限らない. 6-Methyl-prednisolone, Triamcinolone, Dexamethasone 
Fig. 4. Laboratory findings of serum protein and other liver function
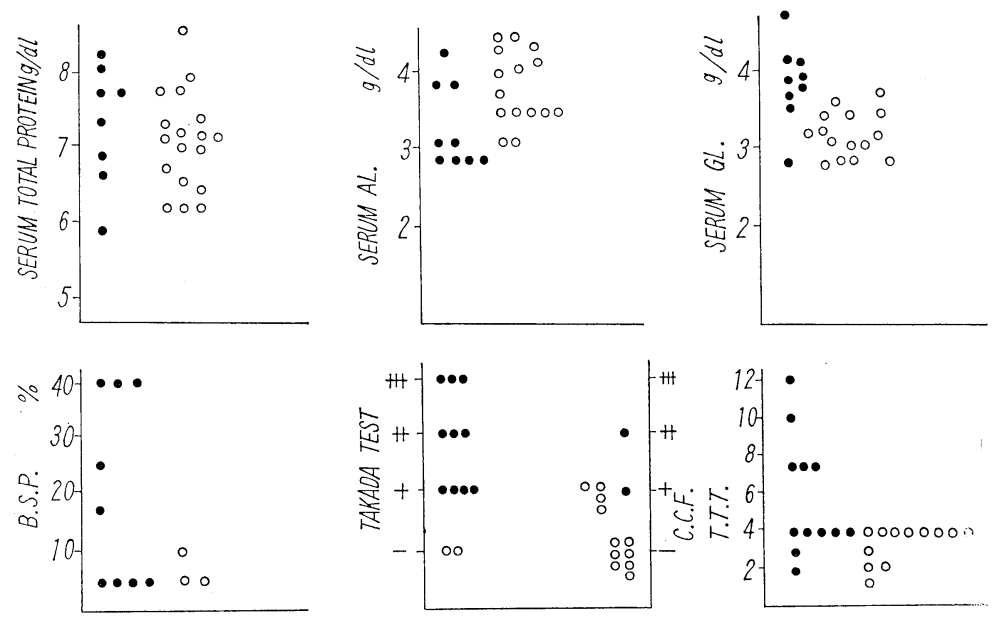

- adrenalectomized patients maintained by Hydrocortisone adrenalectomized patients maintained by Cortisone

Table 4. Long term observations on liver function after adrenalectomy

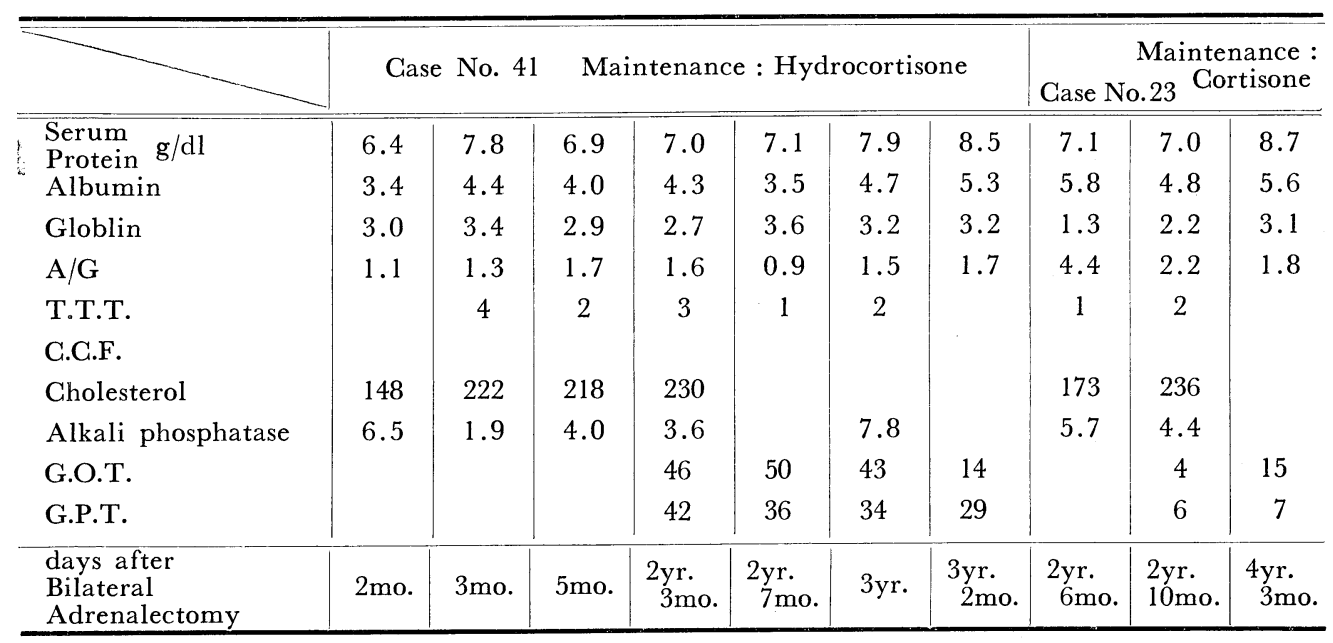

等では長期間の維持が不可能であるので, 従つて肝機能の観察の対象外であるてとはいうまでもない.

4. 糖負荷試験による血糖, 焦性ブドウ酸, 乳酸値の消長について

1）維持 Steroid 別にみた血糖，焦性ブドウ酸，乳酸值（Table 5)

1) 血 糖 值

副婜全剔後の空腹洔血糖值は 65〜 108mg/dl であり，維持別では特に差はみられない.

ロ）焦性ブドゥ酸值

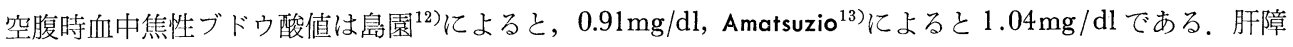
害のない対照者の空腹時血中焦性ブドウ酸值は, Table 6 のでとく $0.7 \mathrm{mg} / \mathrm{dl} \sim 1.32 \mathrm{mg} / \mathrm{dl}$ であつた。平 均值は $0.95 \mathrm{mg} / \mathrm{dl}$ である。 
Table 5. Evaluation of fasting blood sugarpyruvic-acidlactic-acid after adrenalectomy

\begin{tabular}{|c|c|c|c|c|c|c|c|c|c|c|c|c|}
\hline \multicolumn{2}{|c|}{ Maintenance } & \multicolumn{4}{|c|}{ Fasting Blood Surgar } & \multicolumn{4}{|c|}{ Fasting Pyruvic Acid } & \multirow{2}{*}{$\frac{\text { Fasting }}{3.20}$} & \multirow[t]{2}{*}{ Lactic } & \multirow[t]{2}{*}{ Acid } \\
\hline Hydrocortisone & $20 \mathrm{mg}$ & 108 & 68 & 88 & & 1.10 & 1.00 & 0.76 & & & & \\
\hline Hydrocortisone & $30 \mathrm{mg}$ & 90 & 90 & & & 1.10 & 1.04 & 1.10 & 1.06 & 3.80 & 12.0 & \\
\hline Hydrocortisone & $40 \mathrm{mg}$ & 95 & & & & 2.4 & 1.25 & 1.62 & & 5.0 & 2.2 & 12.0 \\
\hline Cortisone & $25 \mathrm{mg}$ & 91 & 76 & 99 & & 0.77 & 1.00 & & & 8.3 & & \\
\hline Prednisolone & $10 \mathrm{mg}$ & 84 & 83 & & & 1.86 & 1.22 & 1.22 & 0.95 & 6.2 & 4.8 & \\
\hline $\begin{array}{l}\text { 6-Methyl } \\
\text { Prednisolone }\end{array}$ & $6 \mathrm{mg}$ & 77 & & & & 1.24 & & & & & & \\
\hline Triamcinolone & $4 \mathrm{mg}$ & 80 & 88 & 72 & 75 & 1.26 & 1.26 & 0.86 & 0.84 & 10.0 & & \\
\hline Dexamethasone & $1 \mathrm{mg}$ & 65 & 87 & & & 1.14 & 1.38 & & & 11.8 & & \\
\hline
\end{tabular}

Table 6. Fasting blood pyruvic acid and lactic acid of control subjects

\begin{tabular}{lcclcc}
\hline Control & Sex & yr. & Diagnosis & $\begin{array}{c}\text { Fasting Pyruvic } \\
\text { Acid (mg/dl) }\end{array}$ & $\begin{array}{c}\text { Fasting Lactic } \\
\text { Acid (mg/dl) }\end{array}$ \\
\hline \hline Imaeda & M & 21 & Appendicitis & 1.10 & 9.65 \\
Kanda & M & 28 & Appendicitis & 1.32 & 18.6 \\
Hasegawa & F & 49 & Mastopathia & 0.88 & - \\
Kawase & M & 50 & Gastric Cancer & 0.70 & 4.1 \\
Takakura & M & 19 & Appendicitis & 0.90 & 6.4 \\
Yoshida & M & 64 & Maxillar Cancer & 0.84 & 11.7 \\
\hline
\end{tabular}

一方，副腎全剔患者の空腹時血中焦性ブドウ酸值は，Hydrocortisone $20 \mathrm{mg}$ 30mg による維持例， Cortisone $25 \mathrm{mg}$ による維持例では $0.76 \sim 1.10 \mathrm{mg} / \mathrm{dl}$ で大体正常範囲にある. Hydrocortisone $40 \mathrm{mg}$ によ る維持では $1.25 \mathrm{mg} / \mathrm{dl} \sim 2.4 \mathrm{mg} / \mathrm{dl}$ と上昇している. Prednisolone, 6-Methyl-Prednisolone, Triamcinolone, Dexamethasone 等による維持例に於いては Hydrocortisone, Cortisone による維持例より焦性ブド ウ酸値は高い傾向にある。

八) 乳 酸 值

空腹時乳酸值は $2.2 \mathrm{mg} / \mathrm{dl} \sim 12 \mathrm{mg} / \mathrm{dl}$ で正常範讲にある.

2）ブドウ糖経口負荷試験による血糖，焦性ブドウ酸，乳酸值の消長について

Fig. 5 のごとく, 正常対照例では，ブドウ糖経口投与後60分に血糖，焦性ブドウ酸值は最高值に達し， 3 時間後には糖負荷前值以下に或いはそれに近い值に下降している. 同様の方法で，副腎全剔患者の術後に ブドウ糖負荷試験を行なつてみると, 先ず血糖曲線は Table 7 のごとく, Hydrocortisone 40mg, Triamcinolone $4 \mathrm{mg}$ による維持例（各1例）はやや diabetic な曲線を示しており，Cortisone による維持例に 曲線の平低化がみられている。

Fig. 6 Hydrocortisone 30mg, Cortisone 25mg, Prednisolone 10mg による維持例では, 焦性ブドウ 酸值は空腹時にはそれぞれ $1.0 \mathrm{mg} / \mathrm{dl}$ 以下の正常範囲にあり，30〜60分後には最高值を示し，3時間後に はいずれも負荷前值に復している。 之を Triamcinolone 6-Methyl-Prednisolone, Dexamethasone によ る維持例についてみると（Fig. 7) 血糖曲線は特に diabetic な曲線を示すものはない，焦性ブドウ酸值は 同じく 30 分〜 60 分後に 最高值を示し，3 時間後に至つても未だ高值にとどまり，ブドウ糖負荷前值に復し ていない. 即ち焦性ブドウ酸值の下降に遷延がみられた。乙れは, Hydrocortisone, Cortisone による維持 例の糖負荷試験と異なるところで, 糖代謝障害の一端が覢われ, 臨床上長期維持に用い難い一つの裏付けと 
なる。乳酸值の消長については，6-Methyl-Prednisolone による維持例に 糖負荷60分後に 著明な上昇をみ た他は特に異常はみられなかつた。

Fig. 5. Serial changes in blood sugar-

pyruvate-lactate response to p.o.

glucose on control subject

( $\downarrow 30 \mathrm{~g}$ of glucose)
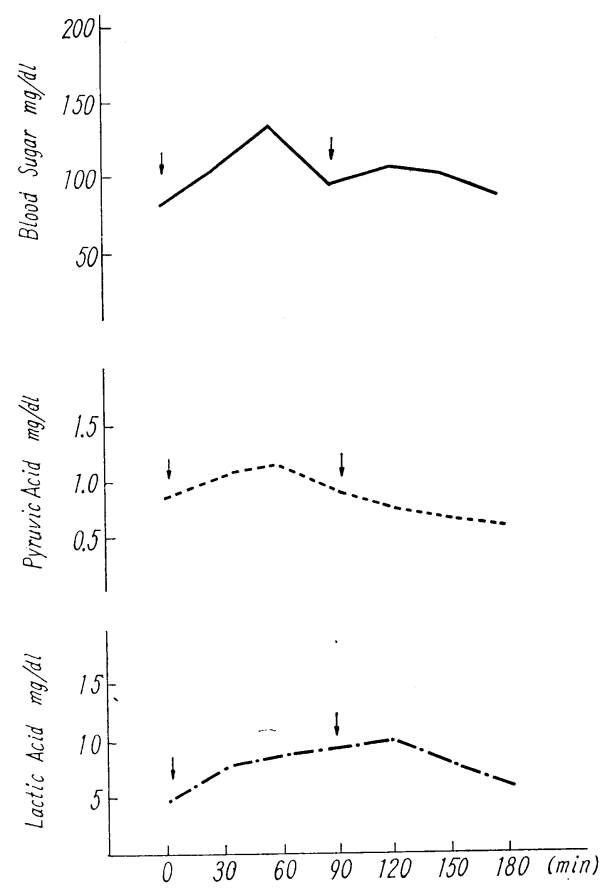

Table 7. Results of glucose tolerance tests performed on adrenalectomized patients

\begin{tabular}{|c|c|c|c|c|c|c|c|c|c|c|c|}
\hline \multicolumn{2}{|c|}{ Patient } & \multirow{2}{*}{\multicolumn{2}{|c|}{ Maintenance }} & \multirow{2}{*}{ Time (min) } & \multirow[t]{2}{*}{ Fasting } & \multirow[t]{2}{*}{30} & \multirow[t]{2}{*}{60} & \multirow[t]{2}{*}{90} & \multirow[t]{2}{*}{120} & \multirow[t]{2}{*}{150} & \multirow[t]{2}{*}{180} \\
\hline No. & $\mathrm{yr}$ & & & & & & & & & & \\
\hline 51 & 37 & Hydrocortisone & $20 \mathrm{mg}$ & $\begin{array}{l}\text { Blood surgar } \\
\mathrm{mg} / \mathrm{dl}\end{array}$ & 85 & 120 & 145 & 110 & 125 & - & 100 \\
\hline 40 & 40 & Hydrocortisone & $30 \mathrm{mg}$ & & 90 & 120 & 127 & 94 & 129 & - & 115 \\
\hline 41 & 57 & Hydrocortisone & $40 \mathrm{mg}$ & & 95 & 115 & 167 & 153 & 190 & - & 150 \\
\hline 23 & 56 & Cortisone & $25 \mathrm{mg}$ & & 95 & 130 & 105 & 121 & 126 & 155 & 128 \\
\hline \multirow[t]{2}{*}{25} & 49 & Cortisone & $25 \mathrm{mg}$ & & 76 & 112 & 152 & 130 & 129 & 141 & 128 \\
\hline & & & & & 99 & 140 & 141 & 168 & 167 & 108 & 72 \\
\hline \multirow[t]{2}{*}{26} & 38 & Cortisone & $25 \mathrm{mg}$ & & 91 & 95 & 100 & 102 & 96 & 102 & 84 \\
\hline & & Prednisolone & $10 \mathrm{mg}$ & & 84 & 121 & 82 & 115 & 139 & 80 & 68 \\
\hline 23 & 56 & Prednisolone & $10 \mathrm{mg}$ & & 82 & 124 & 100 & 80 & 120 & 115 & 82 \\
\hline 52 & 43 & 6-Methyl Prednisolone & $6 \mathrm{mg}$ & & 77 & 170 & 125 & 136 & 159 & 142 & 111 \\
\hline 53 & 52 & Triamcinolone & $4 \mathrm{mg}$ & & 72 & 146 & 150 & - & - & - & 190 \\
\hline 52 & 43 & Dexamethasone & $1 \mathrm{mg}$ & & 83 & 144 & 133 & 106 & 155 & 150 & 106 \\
\hline
\end{tabular}


Fig. 6. Serial changes in blood sugar-pyruvate-lactate response to p.o. glucose

on an adrenalectomized patients

Case No. 51

maintenance of

Hydrocortisone

$20 \mathrm{mg} /$ day
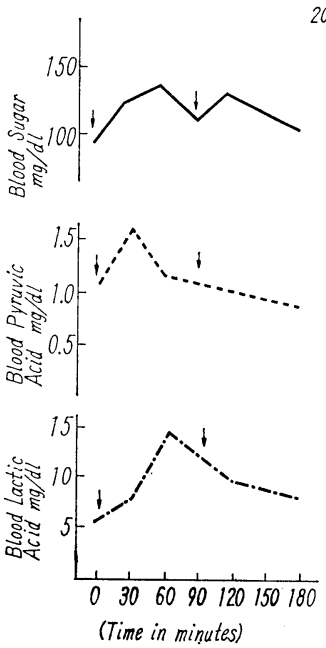

Case No. 26

maintenance of

Cortisone

$25 \mathrm{mg} /$ day

$(\downarrow 30 \mathrm{~g}$ of glucose)

Case No. 26

maintenance of

Prednisolone

$$
10 \mathrm{mg} / \mathrm{day}
$$
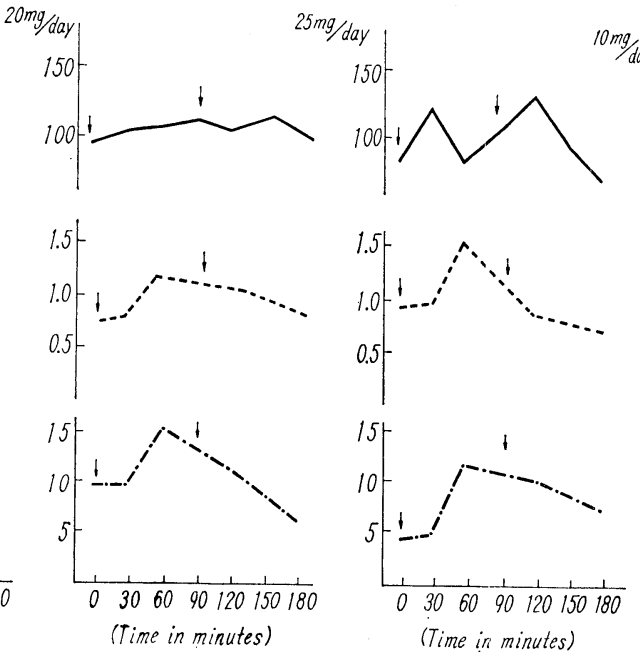

Fig. 7. Serial changes in blood sugar-pyruvate-lactate response to p.o. glucose on an adrenalectomized patients

( $\downarrow 30 \mathrm{~g}$ of glucose)
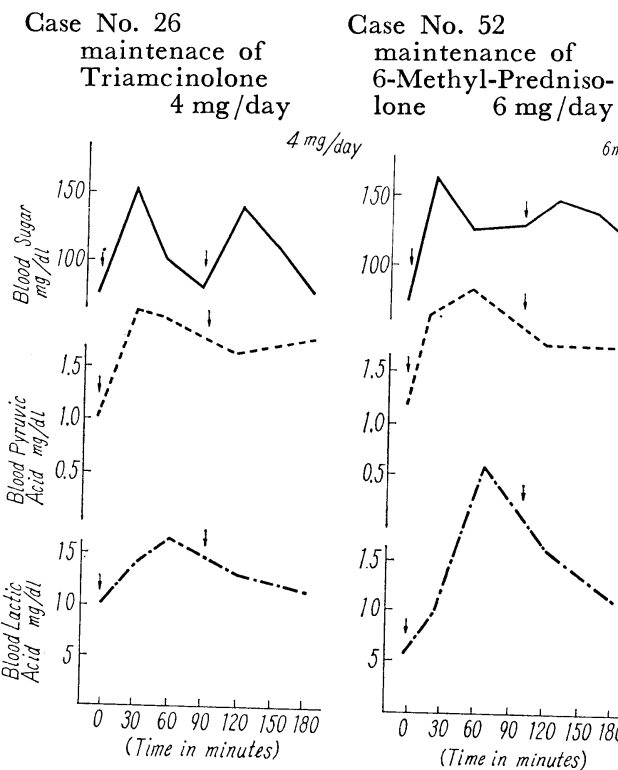

Case No. 52

maintenance of

Dexamethasone

$1 \mathrm{mg} /$ day

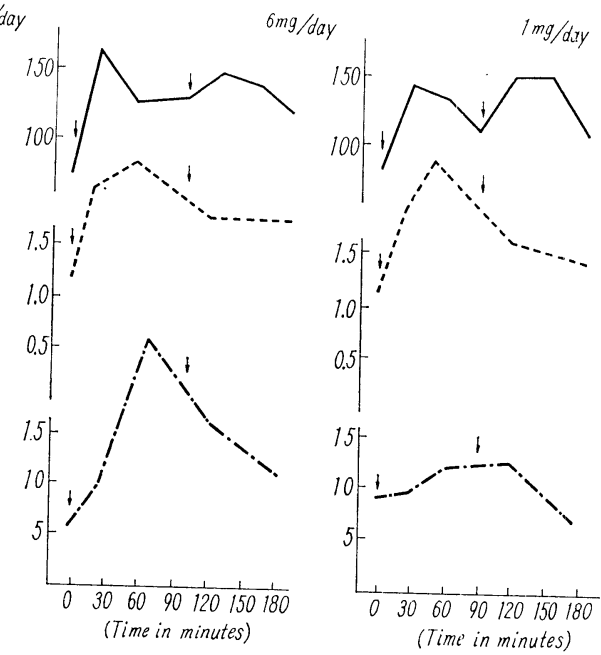

\section{5 、副腎全剔患者の維持中止試験}

副腎全剔患者は，各種のStress に弱く有事の際は危険な状態に陥入る事が考沉られる，患者自身が湢腎 
不全の初期症状を知つておくことは，かかる危険を未 然に防ぐのに役立つ。乙の目的をもつて，教室では副 腎全剔患者の全例に厳重なる監視の下に, 維持中止試 験を行なつている ${ }^{14)}$. すべての症例で中止 $3 \sim 4$ 日に して全身倦急感, 頭重感を訴え, 耳鳴, 眩莗, 嘔気, 嘔吐, 微熱, 冷汗等副腎不全の症状を発現し, テスト を中止せざるを得ぬ状態になつている，維持中止試験 中の空腹時血糖值の消長をみると，Fig. 8 のごとく 5 例中 3 例に $54 \mathrm{mg} / \mathrm{dl} \sim 68 \mathrm{mg} / \mathrm{dl}$ と低血糖の発現を みている，尿中電解質の排泄は，Table 8 のごとく尿 中 $\mathrm{Na}$ の排泄増加，Kの排泄減少がみられる. 血中の 電解質は Table 9 のごとく著変は認められなかつ た. 尚, 副腎全剔後の患者で, 置換療法を必要としな かつた症例は 1 例もなかつた。

\section{6. 副腎全剔患者に対する外科的漫襲}

副腎全剔術の施行にあたつては，その術前術後の埴 換療法は Huggins によると Cortisone の筋注を用
Fig. 8. Effect of cortisone withdrawal or adrenalectomized patients

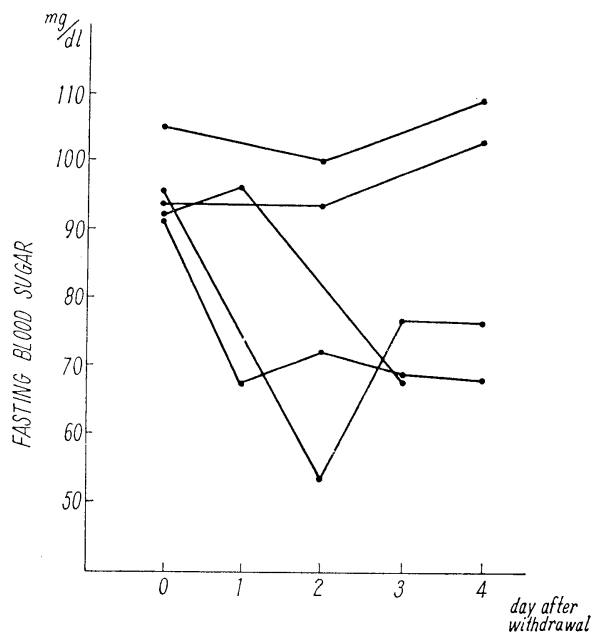

Table 8. Effect of cortisone withdrawal on urinary excretion of sodium, potassium and calcium

\begin{tabular}{c|c|c|c|c}
\hline Case No. & Maintenance & $\mathrm{Na}$ & $\mathrm{K}$ & $\mathrm{Ca}$ \\
\hline \multirow{2}{*}{13} & Cortisone 25mg & 150 & 31.3 & 14.1 \\
& 1st day & 186 & 21.9 & 12.0 \\
& 2nd day & 171 & 20.5 & 12.0 \\
& 3rd day & 208 & 14.7 & 12.8 \\
\hline \multirow{2}{*}{26} & Cortisone 25mg & 153 & 64.7 & 4.9 \\
& 1st day & 195 & 34.7 & 5.4 \\
& 2nd day & 191 & 45.1 & 6.1 \\
\hline
\end{tabular}

いて行なつている，著者らの教室では Hydrocortisone の静注を用いて下記の如き方法で行なつている.

手術前日 DOG $5 \mathrm{mg}$ 筋注

(てれは，副腎全剔術をはじめた初期には DOC の筋注を術前に行なつていたが，現在は用いていな い.)

手術中 Hydrocortisone 100mg 静注

( $5 \%$ ブドウ糖 $500 \mathrm{cc}$ に混入，総量 $100 \sim 200 \mathrm{mg}$ )

術後第 1 日 Hydrocortisone $200 \mathrm{mg}$ 静注

$\begin{array}{llrl}\text { 第2 日 } & \text { 日 } & 150 \mathrm{mg} " \\ \text { 第3 日 } & \text { " } & 100 \mathrm{mg} " \\ \text { 第4 日 } & \text { " } & 60 \mathrm{mg} \text { 経口 }\end{array}$

第 5 日 以後漸減して維持量 Hydrocortisone $20 \mathrm{mg} /$ day とする.

Hydrocortisone Sod. Succinate (Solu-Cortef-Uptohn) を用いて静脈投与を行ない，術中術後の管理を 安全に行なうことができる。 
Table 9. Effect of hydrocortisone withdrowal on serum electrolyte level

\begin{tabular}{c|c|c|c|c}
\hline Case No. & Maintenance & Na mEq/L & $\mathrm{K} \mathrm{mEq} / \mathrm{L}$ & $\mathrm{Cl} \mathrm{mEq} / \mathrm{L}$ \\
\hline \hline \multirow{3}{*}{45} & Hydrocortisone 20mg & 146 & 2.7 & 100 \\
& 1st day of withdrawal & 148 & 3.1 & 92 \\
& 2nd day of withdrawal & 148 & 4.2 & 96 \\
& 3rd day of witndrawal & 144 & 3.8 & 93 \\
\hline \multirow{3}{*}{46} & Hydrocortisone 20mg & 140 & 4.1 & 105 \\
& 1st day of withdrawal & 149 & 4.7 & 103 \\
& 2nd day of withdrawal & 142 & 5.3 & 95 \\
& 3rd day of withdrawal & 138 & 5.9 & 90 \\
\hline
\end{tabular}

術後経口投与が可能となれば速かに Hydrocortisone の鍍剤を経口的に投与している.

生体に外科的浸襲が加わる場合には，副腎皮質機能が充進し， Steroid-hormone の産生が増加するとと は知られている15116). しかるに副腎全剔患者に於いては，経口的に投与されている exogene な Steroidhormone は，日常生活に於て健康を保持するに必要な維持量であり，乙の他に分泌源はないので，当然て れら副腎全剔患者に外科的浸襲を加える場合は，Hydrocortisone の投与量を增さなければならない，教室 では副腎全剔患者 7 名に種々の外科的浸襲か加えられ，副腎不全症状の発現もなく Table 10 のごとく

Table 10. Operations performed on totally adrenalectomized patients

\begin{tabular}{|c|c|c|c|c|c|c|c|c|c|c|c|}
\hline Case No. & Operation & $\begin{array}{l}\text { Days after } \\
\text { adrenalectomy }\end{array}$ & $\begin{array}{l}\text { before } \\
\text { Operation }\end{array}$ & $\begin{array}{l}\text { Operations } \\
\text { n day }\end{array}$ & 1 & 2 & 3 & 4 & 5 & 6 & 7 \\
\hline 25 T.N. & r-Mastectomy & $2 \mathrm{yr} .8 \mathrm{mo}$. & & H.C. $300 \mathrm{mg}$ & 80 & 40 & 40 & 40 & 40 & 30 & $20 \mathrm{mg}$ \\
\hline 30 T.O. & $\mathrm{r}$-Mastectomy & $2 \mathrm{mo}$. & DOC 5mg & H.C. $200 \mathrm{mg}$ & $\begin{array}{l}100 \\
\text { Cortis }\end{array}$ & $\begin{array}{r}75 \\
\text { sone) } \\
\end{array}$ & 50 & 50 & 50 & 50 & $25 \mathrm{mg}$ \\
\hline 32 T.Y. & $\begin{array}{l}\text { Incision of } \\
\text { abscess }\end{array}$ & $1 \mathrm{mo}$. & DOG 5mg & H.C. $100 \mathrm{mg}$ & $\begin{array}{c}10 \\
\text { Predn }\end{array}$ & $\begin{array}{c}10 \\
\text { nisolor } \\
\end{array}$ & ne) & 10 & 10 & 10 & $10 \mathrm{mg}$ \\
\hline $45 \quad$ T. & $\begin{array}{l}\text { local Removal } \\
\text { of tumor }\end{array}$ & $3 \mathrm{mo}$. & & H.C. $100 \mathrm{mg}$ & 20 & 20 & 20 & 20 & $20^{\prime}$ & 20 & $20 \mathrm{mg}$ \\
\hline 48 M.T. & $\begin{array}{l}\text { frontal } \\
\text { Graniotomy }\end{array}$ & $2 \mathrm{mo}$. & DOG $5 \mathrm{mg} \quad \mathrm{I}$ & H.C. $300 \mathrm{mg}$ & 150 & 150 & 80 & 80 & 80 & 40 & $40 \mathrm{mg}$ \\
\hline 53 S.K. & $\begin{array}{l}\text { Tumor } \\
\text { extirpation }\end{array}$ & $1 \mathrm{mo}$. & & H.G. $300 \mathrm{mg}$ & 200 & 120 & 120 & 80 & 80 & 60 & $40 \mathrm{mg}$ \\
\hline 64 Y.I. & $\begin{array}{l}\text { Tumor } \\
\text { extirpation }\end{array}$ & $1 \mathrm{mo}$ & & H.C. $100 \mathrm{mg}$ & 20 & 20 & 20 & 20 & 20 & 20 & $20 \mathrm{mg}$ \\
\hline
\end{tabular}

Hydrocortisone の增量により安全に手術を施行している，膿瘍切開，小腫瘤の摘出術等比較的手術浸襲が 小さい時は, 術中 Hydrocortisone 100mg を静注, 術後は第1 日目より直ち亿維持量に移行している。し かし, 乳房切断術等全身麻酔を行ない, 大きな手術浸襲の加わる場合は, 副腎全剔術の場合潐じて置換療 法を行なえば安全に手術を行なうことができる，副腎全剔患者 7 名に対して，外科浸襲が加えられたが，1 例も shock をおてさず術後も良好に経過している。 


\section{IV 考按}

Pfiffner ${ }^{17)}$ ，Rogoff ${ }^{18)} ら は 1929$ 年にはじめて副婜全剔犬の維持を adrenal extract を用いて行ない，生命維 持の延長に成功しての物質を Interrenaline と呼んだ。更にてれと時期を同じくして，Hartmanら ${ }^{19)} は$ adrenocortical extract を用いて副腎剔出猫の維持に成功している.

1945年に至り Huggins ${ }^{20)}$ は人の副腎全剔患者にはじめて adrenocortical extract 5〜10cc と DOC 用い てその維持を行なつた。 1946年には Surretにより Cortisone が抽出されて1948年には臨床的に応用され るようになり，副腎全剔患者の維持が容易になつて来た。

1952年に Huggins ${ }^{1)}$ は広汎な局所再発，遠隔転移を持つ所謂末期乳癌患者に対して両側副腎全剔を行な つて效果を収めて以来，諸家によつて試みられて来た。しかし副腎全剔術を施行された患者は，術後種々の 困難な問題に直面しなければならない，即ち，感染，外傷等のStress に対し自動的に対処するてとができ ないからである。よつて副腎全剔術後の replacement therapy は注意深い観察の下になされなければなら ない.

1 日の Glucocorticoid の投与量についてみると, 投与法は諸家により異なり一定していない.

Buttler ${ }^{21)}$ は Cortisone 25〜50mg/day t 1 日 2 回に分けて投与している. Cade ${ }^{22)}$, Pearson ${ }^{23)} ら は$ Cortisone $50 \mathrm{mg} /$ day を単独投与している. Cortisone $50 \mathrm{mg}$ により糖尿をみたときには Cortisone $37.5 \mathrm{mg}$ に減じ $0.1 \mathrm{mg} \sim 0.3 \mathrm{mg}$ の Hydrocortisone acetate を加えると糖尿が消失するといつている，Na-眝溜 作用を補う意味では，F.A. Coller ${ }^{24)}$ は 9-alpha-Fluorohydrocortisone を加えて Hydrocortisone 37.5mg /day そより維持を行なつている。 Galante ${ }^{5)}$ は1955年に Cortisone $37.5 \mathrm{mg}$ と DOC $25 \mathrm{mg} \sim 50 \mathrm{~m} \mathrm{~g}$ 月に 1 回投与し，血压を正常に保ち $\mathrm{Na}$ の整失を防ぐのに役立つといつている. 又 Simkin $^{25}$ は Cortisone $37.5 \mathrm{mg}$ 〜 50mg に DOG 2mg を毎日舌下に投与している. 之に対し Huggins ${ }^{1)}$ は Cortisone 37.5mg〜50mg で維 持され，DOG の投与の必要はないと述べているが食慨には 2 ～ 4 の食塩を加えている.

副腎全剔動物の生命維持は，電解質作用が主体である DOC，Aldosterone でも可能だが，てれのみでは 勿論副腎全剔後の維持は不可能である。 又 DOG は生体内で Estrogen への転換が推定されており ${ }^{26)}$ 乳癌 患者に用いるととは好ましくないと思われる。C. Franksson は先に Cortisone $50 \mathrm{mg} \sim 75 \mathrm{mg} /$ day に DOC 1mg〜2mg を用いて replacement therapy を行なつており, 1956年には副腎全剔患者81名に Cortisone 50mg 1 例に62.5mg，19例には75mgのが必要であつたと述べているが゙2)，教室の Cortisone により維持された14 例は 1 日 $25 \mathrm{mg}$ で充分であり，彼等は極めて大量を用いているといえよう。乙れは欧米人と日本人との体軀 の差によるものであろうか. 更に Franksson は Prednisolone 10mg でも維持が可能だとしており, 又 9 例を Hydrocortisone 20〜50mg で維持している。著者も Prednisolone 10mg で自他覚的に副作用なく 35 日間維持できた症例を経験している。先にBondy ${ }^{7)} 1$ 日に分泌される cortisol を測定し，人の副腎からは $25 \mathrm{mg} の$ cortisol が分泌されると述べている. 最近は Isotope dilution method により測定されているが， それによると 1 日の Cortisol 分泌量は Cope ${ }^{27)}: 4.9 \sim 27.9 \mathrm{mg}$. Flood : ${ }^{28)} 12.2 \sim 20.5 \mathrm{mg}$, Romanoff ${ }^{29)}: 15.9 \sim$ $31.3 \mathrm{mg}$ である。教室では，Hydrocortisone $20 \mathrm{mg} /$ day を基準として用い，生理的に長期間維持できると いう点で最適な Glucocorticoid であると考えている.

Triamcinolone, 6-Methyl-Prednisolone, Dexamethasone 等の維持では, 尿中 Na 排泄増加がみられる. これは Na-貯溜作用の少ない Glucocorticoids であるととから当然考えられることである。 6-MethylPrednisolone $8 \mathrm{mg} /$ day にDOG $5 \mathrm{mg}$ 週 2 回，Dexamethasone に DOG を併用して維持を行なうと，自覚 的には比較的副作用なく用い得るが，水分， $\mathrm{Na}$ 貯溜等他覚的には異常がみられ，電解質作用の調整がむづ かしく又投与法が繁染隹で長期間の維持には適さない.

Henken ${ }^{30)}$ は副腎剔出動物の salt taste threshold について研究し, 副腎剔出後は salt taste threshold の值が低下し, Glucocorticoid の投与で正常化すると述べている。乙の閾值低下の機序は明らかにされてい ないが，副腎不全の時の $\mathrm{Na}$ 言失，食塩に対する㫮好の問題と関連して興味深い. Addison 氏病患者が特 
に食塩に対する嗜好が強いととは知られており，Thorn ${ }^{31) 32)}$ らによると，68例の Addison 氏病患者の中16 \%に食塩に対する強い嗜好がみられたという。 この場合副腎は，hypo〜dysfunction の状態にあると想像 され，且つ慢性の副腎不全が続いており，乙の点で副腎全剔後，適切に replacement therapy が行なわれ ている状態とは明らかに相違がある，教室の副腎全剔患者では特に食塩に対して強い嗜好を示した症例は 1 例もなかつた. Buttler ${ }^{18)}$ は患者の食慨には約 $6 \mathrm{~g}$ の食塩が含まれていると述心゙ているが，日本人の食餌に は普通約 $18 \mathrm{~g}$ の食塩が含まれており，欧米人との食生活の相違を，食塩を特に必要としない理由の一つにあ げるととができると考える。

Steroid-hormone は代謝系に関与し，Steroid hormone 自身の代謝は肝に於いて行なわれるとされている. 従つて副腎全剔患者に対して，長期間にわたり Steroid hormone を投与する場合，その代謝の場を提供する

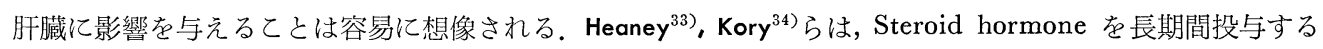
と B.S.P の排泄遅延がおきると述べている。 Friedgood ${ }^{35)}$, Bermer $^{36)}$ らは，副腎剔出動物の肝機能障害は Glucocorticoid の投与で改善されるといつている.Begg ${ }^{37)}$ とると副腎剔出ラッテでは肝に於けるCatalase activity の低下が来るという。 又,久米 ${ }^{38)}$ は副腎剔出マウスで肝蛋白の減少, 肝 catalase 活性 cholinestelase 活性の低下並びに血清アルブミンの低下を認めている，教室のCortisone による維持群には血清アルブミン の低下と血清グロブリンの上昇がみられている。がしかし，Cortisone による辰期間の維持例に朋機能障害 のない症例もあり，全例に肝機能障害が来るとは限らない. Hydrocortisone による維持群には肝機能障害 を来したものは少ない．との点からも Hydrocortisone による維持が優れていると考える。教室の吉田は, 副腎全剔術後が副腎脾静脈吻合術後に比して肝障害の発現率が高いてとに注目し ${ }^{39)}$, 肝機能障害は副腎皮質 機能の廃絶により，二次的に発現したと考えているが，ての問題に関しは内因性の Steroid 久除が重要な役 割を演じていものと思われる。

今日副腎が糖代謝に重要な役割を演じているというととは明らかであり， Long ${ }^{40)}$, Cori $^{41)}$, Britton $^{42)}$ 等数 多くの研究者によつて示されている，従つて副腎全剔患者は, 術後適切な replacement therapy がなされ なければ糖代謝に障害がくるととは容易に想像される。よつて副腎全剔後に於いて糖代謝障害の有無を知る ことは有意義である。かかる観点より，ブドウ糖を負荷して糖代謝について検傠を加えた。

血糖曲線については, Hydrocortisone $40 \mathrm{mg}$, Triamcinolone $4 \mathrm{mg}$ 維持例にやや diabetic な曲線が得ら れた．空腹時焦性ブドウ酸值もこの 2 例は高い值を示している. Hydrocortisone を1日 $40 \mathrm{mg}$ を必要とし た症例は少ないが，維持量としては多すぎて好ましくないと思われる.

Hydrocortisone 20mg, Cortisone 25mg, Prednisolone 10mg による維持例では, 正常対照例と同様の 二双性を示し，3時間後には，ほぼ糖負荷前值に復している．焦性ブドウ酸值については，ブドウ糖負荷後 30〜60分後に最高值に達し 3 時間後には，負荷前值に復した。乳酸值は，焦性ブドウ酸值とほぼ平行関係に ありて，異常は認められない.

一方，6-Methyl-Prednisolone 6mg, Triamcinolone 4mg, Dexamethasone $1 \mathrm{mg}$ による維持例では，血 糖曲線については特に diabetic な曲線を呈するものはないが，焦性ブドウ酸值は 30〜60分後に最高值を示 し，3 時間後にも尚高值にとどまり，ブトウ糖負荷前值に復していない．乙れは，Hydrocortisone, Cortisone 等による維持例のブドウ糖負荷試験と異なるところで，糖代謝障害の一端が窺われ，臨床上長期間 維持に用いがたい一つの裏付けとなる。

糖質代謝の中間代謝産物として重要な焦性ブドウ酸の消長を主なる主標として糖処理能の面より副腎全剔 後の維持について検討を加えた。この様に焦性ブドウ酸值の上昇には，1) Beuding ${ }^{43)}$ の指摘したように，ビ タミン $\mathrm{B}_{1}$ の欠文による場合，次に 2) 焦性ブドウ酸の酸化はビタミン $\mathrm{B}_{1}$ のピロ燐酸化により促進されるが， この過程に障害がある場合，3) acetyl-CoA への焦性 ブドウ酸の転化の阻害，蛋白よりの gluconeogenesis 等が考えられる。 この点を解明するために，6-Methyl-Prednisolone, Triamcinolone, Dexamethasone による維持例にブドウ糖と同時にビタミン $\mathrm{B}_{1}$ を負荷して検討したとてろ Triamcinolone による維持 例にはビタミン $\mathrm{B}_{1}$ により焦性ブドウ酸值の下降はみられず, 又 3 時間尿中ビタミン $\mathrm{B}_{1}$ 量が増加し, 井上 ${ }^{44)}$ 
の提唱せるビタミン $\mathrm{B}_{1}$ の利用障害を思わしめる結果が得られた ${ }^{45)}$. Soffer ${ }^{6)}$ にれ れ゙ 6-Methyl-Prednisolone, Triamcinolone の糖質効果は, Cortisone の約 6 倍, Dexamethasone のそれは約30倍強いので, Henneman が想定したように acetyl-CoA への焦性ブドウ酸の転化の阻害，蛋白よりの gluconeogenesis の増加，fatsynthesis の減少等も考慮に入れなければならないと考える。しかし，Hydrocortisone で維持 するときはこの様な障害はみられない.との点からも長期間の維持に適しているといえよう。

副腎全剔患者には，術後1 ケ月以上経過してから，Steroid の維持中止試験を行なつている。乙れは二つ の目的をもつて行なわれた。 即ち一つは先述したように患者は各種の Stress に弱く有事の際は危険な状態 に陷入るととが考えられる。よつて副腎不全の初期症状をよく知らせ，不全症状の発現を未然に防ぐことは 維持を安全に行なう上に極めて大切なてとである。第二には，術後の再燃に関して補副腎の存在が霓々問題 となるが，副腎全剔後に生命を保持するに充分な補副腎があれば， replacemen therapy は不必要となるで あろう。このことから間接的に補副腎の有無を知ることができる．以上二つの目的をもつて厳重なる監視の 下に維持中止試験が行われたのである。. Steroid 維持中止後, 空腹時血糖值の消長を観察した 5 例中 3 例に 低血糖の発現をみた。必ずしも全例に低血糖がくるとは限らない，動物実験と異り不全症状が激化する前に glucocorticoid の投与を再開しなければならず，完全なる不全症状をみるととはできないてとから当然とい へる. 尿中 Na の排泄は増加し，Mendelssohn ${ }^{46)}$ ， Lipset ${ }^{47)}$ らの認めたでとく全例に維持中止 $3 \sim 4$ 日後に副 腎不全の症状が発現した。 Graham ${ }^{48)}$ は 100例の剖検例中32例に補副腎を見出しており,Soffer によると或種 の動物は complete accessory adrenal gland を持つているのが普通であるが，人間では16\%に補副腎を持 つていると述べている ${ }^{49)}$. しかし, 教室の症例では, 中止テストの結果として, 生命を維持するに足る程の 有力な副腎組織の存在を否定するてとができるであろう.

以上副腎全剔術後の維持を各種合成 Steroid を用いて検討した結果，Hydrocortisone $20 \sim 30 \mathrm{mg} / \mathrm{day}$ に よる単独の維持で，DOC， NaCl の投与を必要とせず長期間何ら副作用なく一般状態を正常に保つことがで き, replacement therapy として最適であるととを強調したい.

尚副腎全剔患者中 1 例に食中毒による下痢が原因となり，副腎不全を誘発した。 大量の Hydrocortisone のみでは症状の改善はみられず DOG の投与, 電解質液の補液によりはじめて危機を脱し得た。脱水，電 解質袈失による副腎不全には Hydrocortisone のみでなく DOC の投与, 水分, 電解質の輸液は不可欠で あるととは言を俟ない.

\section{V. 結 論}

1956年より1963年に至る 7 年間に，今永外科教室に於いては，末期乳癌患者43名に対し両側副腎・卵巣剔 出術が行われた。 これら副腎全剔患者を対象に，Hydrocortisone, Cortisone, Prednisolone, 6-Methl Prednisolone, Triamcinolone, Dexamethasone の6 種の合成 Steroid を用い，その維持について 検討し た結果, 次の如き結論を得た.

1) 臨床症状の観察から, Prednisolone, 6-Methyl-Prednisolone, Triamcinolone, Dexamethasone によ る維持では, Hydrocortisone $20 \mathrm{mg}$ の糖質作用に相当する量では, 血圧下降, 全身倦急, 嘔気, 嘔吐等副 腎不全の症状か溌現し, 長期間の維持は不可能である.

2) 尿中電解質の排泄については, Prednisolone, 6-Methyl-Prednisolone, Triamcinolone, Dexamethasone による維持例の尿中Na排泄量は増加している. Hydrocortisone, Cortisone による維持例の尿中 $\mathrm{Na}$ の排泄量は正常範囲にあり，血中電解質にも異常はみられない.

3) ブドウ糖負荷試験の成績から,

(1) Hydrocortisone, Prednisolone による維持例では, 血糖曲線で血糖値の異常な上昇, 遷延はみられ ない，焦性ブドウ酸值は，30〜60分後に最高值に達し 3 時間後には負荷前值に復する．乳酸值もほぼ焦性ブ ドウ酸曲線と平行関係にある。

(2) 6-Methyl-Prednisolone, Triamcinolone, Dexamethasone による維持例では, 血糖曲線でや 第 40 巻、第 12 号 
や diabetic な曲線を示したものがあり，乳酸值の異常な上昇をみた例があつた．焦性ブドウ酸值は糖負荷 後30〜60分後に異常な上昇を示し，3 時間後も高值にとどまつた.

4) Cortisone による維持群に血清アルブミンの低下，血清グロブリンの上昇がみられ，B.S.P の排泄遅 延等肝機能障碍が半数にみられた。

5）副婜全剔術後，replacement therapy を中止して観察したとしろ，3〜 4 日にして全例に副腎不全の 症状発現し，置換療法の不要な症例はなかつた。

6) 以上の諸点から，副腎全剔患者は，Hydrocortisone $20 \sim 30 \mathrm{mg} / \mathrm{day}$ で最も生理的に且つ長期間維持 が可能であり， DOC， NaCl 等の投与は不必要であるととが知られた。

(本諭文の要旨は, 第60回日本外科学会総会の宿題報告「副腎の外科」(1960), 第33回, 第35回, 第37回 日本内分泌学会総会に於いて発表した.)

終りにのぞみ, 常に御指導, 御教示を賜つた恩師今永教授, 永井助教授に心から感謝致します. 又終始直 接の御指導走いただいた仙石光彦, 吉田穣両博士並びに内分泌研究班諸学兄に心から感謝の意を表します。

\section{References}

1) GHALES HUGGINS DERBERT M. BERGENSTAL : J.A.M.A., $147: 101$, (1951).

2) $\mathrm{GU}$ RT FRANKSON, JOHN HELLSTRÖM : Acta Chir. Scand., 111 : 54, (1956).

3) V.P. HOLLANDER, C. D. WEST, W.F. WHITEMORE, H.T. RANDALL, O.H. : PEARSON, Gancer, 5 : 1019, (1952). 4) A.A. FRANGIA, A.I. HOLLEB, J.H. FARROW, N.E. TREBES, H.T. RANDALL, W.H. WHITEMORE, GANCER, $12: 58$, (1959).

5) MAURICE GALANTE, H.J. McCOCKLE : Am. J. Surg., $90: 180$, (1955).

6) J.L. SOFFER, R.I. DORFMAN, J.L. GABRILOVE, : The human adrenal gland, (1961).

7) BONDY P.K., ALTROGK J.R., : J. Glin. Invest., $32: 703$, (1953)

8) CLIFT F.P., GOOK R.P. : Biochem. J., 26 : 1800, (1932).

9) FREEDMAN T.E., HAUGEN G.E. : J. Biological Chem., $147: 415$, (1943). 10) SHIMIZU : Medicine and Biology, $17: 2$, (1950). 11$)$ S.B. BARKER, W.H. SUMMERSON : J. Biol. Chem., 138 : 535, (1941). 12) SHIMAZONO : Vitamin, $5: 76,(1952) . \quad 13)$ AMATUZIO, D.S. NESBIT, S. : J. Glin. Invest., $29: 1486$, (1950). $\quad 14)$ RYOJI NAGAI, : J. Jap. Surg. Soc., $61: 1021,(1960)$. 15) FRANKSSON C. et al : Acta Physiol. Scand., $31: 1$, (1954). 16) FRANKSSON G. \& GEMZELL, C.A. : J. Clin. Endocrin. and Met., 15 : 1069, (1955). 17) PFIFFNER, J.J. SWINGLE, W.W. : Anat. Rec., 44 : 225, (1929).

18) ROGOFF, J.M., STEWART, G.N. : Science, 66 : 327, (1929). 19) HARTMAN, F.A., MacARTHUR, G.G., HARTMAN, W.E. : Proc. Soc. Exper. Biol. Med., $25: 69$, (1927). $\quad$ 20) G. HUGGINS, W.W. SCOTT : Ann. of Surg., 122 : 1031, (1945). $\quad 21)$ W.S. BUTTLER, J.T. GRAYHACK, G.L. RANSON, W.W. SCOTT : J. of Urol., $70: 657$, (1953). $\quad$ 22) SIR S. CADE : Brit. Med. J., $1: 1$, (1955). 23) V.P. HOLLANDER, C.D. WEST, W.F. WHITEMORE, H.T. RANDALL, O.H. PEARSON : Cancer, $5: 1019$, (1952). 24) G.E. BLOCK, A.B, VIAL, J.D. MacGARTHY, G.W. PORTER, F.A. GOLLER : S.G.O., 118, (1955). $\quad$ 25) B. SIMKIN : California Med., 87 : 383, (1957). 26) R.I. DORFMAN, FRANK UNGER : Metabolism of Steroid Hormones, publication, (1954). 27) COPE, G.G., BLAGK, E. : Brit. Med. J. No. 5078, (1958). 28) FLOOD, G., LAYNE D.S. : Acta Endocrin., $36: 237$, (1961). 29) ROMANOFF, L.P., MORRIS, C.W. : J. Clin. Endocrin. \& Met., 21 : 1413, (1961). $\quad 30)$ R.I. HENKEN, D.M. SOLOMEN : J. Clin. Endocrin. \& Met., 22 : 856, (1962). 31) THORN, G.W., DORRANCE, S.S., DAY, E. : Ann. Int. Med., 16 : 1053, 第 40 巻 第 12 号 
(1942). 32) THORN S.W. : Diagnosis of adrenal insufficiency and treatment. publication, (1951). $\quad 33)$ HEANEY R.P., WHEDON G.D. : J. Lab. Clin. Med., 52 : 169, (1958). 34) R.C. KORY, M.H. BRADLEY, R.N. WATSON, R. GALLAHAN, B.J. PETERS : Am. J. Med., 26 : 243, (1959). $\quad 35)$ C.E. FRIEDGOOD, H.M. VARS, J.W. ZERBE : Am. J. Physiol., $163:$ 354, (1950). 36) D. BERMER, M. SYLVESTER, E.C. HAY, HANS SELYE : Endocrin., 41 : 258, (1947).

37) BEGG, R.W., RENOLD, E.F. : Science, $111: 721$, (1950). 38) KUME : Folia Endocrin. Jap., $35: 345$, (1959). 39) YOSHIDA : J. Nagoya Med.Ass., $84: 1$, (1959). 40) C.N.H. LONG : Endocrin., 26 : 309, (I940). 41) CORI, G.F., CORI, G.T. : J. Biol. Chem., 64 : 473, (1927).

42) BRItTON, S.W., SIlbetT, H. : Am. J. Physiol. $100: 701$, (1932). 43) ERNEST BEUDING, M.H. STEIN, H. WORTIS : J. Biol. Chem., $140: 697,(1941) . \quad 44)$ INOUE : Progess in Vitamin, part 2, 67. 45) IMANAGA : Vitamin, $27: 477$, (1963). 46) M.L. MENDELSSOHN, O.H. PEARSON : J. Glin. Endocrin. \& Met., $15: 409$, (1955). $\quad 47)$ M.B. LIPSET, C.D. WEST, J.P. MacLEAN, O.H. PEARSON : J. Glin. Endocrin. \& Met., $17: 354$, (1957). 48) GRAHAM, L.S. : Cancer, $6: 149$, (1953). 49) J.L. SOFFER, R.I. DORFMAN, J.L. GABRILOVE : The human adrenal Gland, (1961). 